\title{
LEGAL PROTECTION AND SOCIAL REINTEGRATION OF HUMAN TRAFFICKING VICTIMS
}

\author{
A. ARMEANU
}

\section{Andrei ARMEANU}

Jurist, Universitatea "Alexandru Ioan Cuza", Facultatea de Drept, Iași

Adresa de corespondenţa: Andrei Armeanu, Aleea Başotă, nr. 6, ap. 41, Iași, jud. Iași

E-mail: andrei_armeanu@yahoo.co.uk

\begin{abstract}
:
As of April 2019 the Romanian authorities have expanded the protective measures to which victims of crime will have access through Government Ordinance 24/2019. This legislative amendment is designed to harmonise national legislation with the full provisions of the European Directive 2012/29/EU laying down minimum rules on the rights, support and protection of victims of crime. These changes are welcome given previous legislative loopholes and worrying statistics as the phenomenon of trafficking in human beings is growing in Romania. This paper is reviewing recent legislative changes and proposes an analysis of the protection and support measures available for victims of trafficking in human beings in Romania.
\end{abstract}

KEYWORDS: assistance for victims of human trafficking, victim protection policies, court proceedings, European Directive 2012/29/EU, the role of legal and judicial authorities

\section{INTRODUCTION}

Trafficking in human beings is a global phenomenon. In all its forms, this crime seriously damages the dignity and physical integrity of an increasing number of women, men and children worldwide.

The United Nations (2000) defines human trafficking as the recruitment, transportation, or receipt of persons through some form of threat or coercion, particularly those that abuse positions of power and take advantage of the vulnerability, for exploitation including prostitution, servitude, or the removal of organs.

Based on this definition, victims of human trafficking can fall into several subpopulations along two dimensions ${ }^{1}$.

The first dimension is the type of trafficking experienced, the subpopulations of which include commercial sex, forced labour, involuntary servitude, and domestic violence.

The second dimension is the type of individual targeted, the subpopulations of which include domestic or international victims, minors, individuals with special needs, and the children of victims being trafficked.

Trafficking in human beings is often transnational in nature, but this is not always present. Cultural and linguistic barriers and the terror of victims make this crime very difficult to investigate. Despite the background of the majority of victims in politically unstable or economically vulnerable countries, this phenomenon also affects developed countries, which are becoming markets for human traffickers.

\footnotetext{
${ }^{1}$ Pascual-Leone, A. (2016) "Working with Victims of Human Trafficking" The Journal of Contemporary Psychotherapy, p. 130
} 
In particular, after accession to the European Union, Romania is affected by this criminal scourge, while being both a country of origin and a transit country for human trafficking networks in eastern Europe.

In the given context, the Romanian authorities have faced two challenges: To protect the national population from potential recruitment in continental networks of prostitution and forced labour, and to provide guarantees to ensure the protection and rehabilitation of victims, as required by the European Union. Slow developments in the fight against trafficking in human beings, the annual increase in the number of trafficked Romanian citizens, and even the emergence of wholly shocking modern slavery, lead us to the idea that this issue is topical and of particular interest in the light of the threat posed by organized crime to the safety of the population and national security.

The main purpose of this work is to present the latest legislative provisions adopted by the Romanian authorities and to assess the impact they can have for victims of human trafficking.

As a secondary objective, the work will present a series of proposals to improve social rehabilitation and relief measures (psychological, legal and financial) for victims of trafficking in human beings.

\section{PROTECTION, ASSISTANCE AND SOCIAL REHABILITATION OF VICTIMS OF TRAFFICKING IN HUMAN BEINGS.}

As a result of the traumas suffered by victims of human trafficking have complex needs and thus access to the wide range of services.

Victims often experience various psychological symptoms after experiencing exploitation, physical violence, or psychological violence. They may present a mix of symptoms, including symptoms that originated before the experience, those that were a result of trafficking, and those experienced after release. Psychological disorders and symptoms that are common among victims of human trafficking include symptoms of posttraumatic stress disorder (PTSD), depression, anxiety disorders, dissociative disorders, and substance abuse disorders. This complex of factors, amplified by pre-existing conditions, plays a fundamental role in the vulnerability of the victim ${ }^{2}$.

Victims of human trafficking face an extensive battle when trying to heal from their experience and have varying needs at different stages of their recovery process. In the immediate term, victims require safety, clothing, housing, and crisis intervention.

In the short-term, victims require physical and mental health treatment and some appropriate coordination between these. Victims may also have needs that interfere with receiving treatment, such as a lack of language interpreters, lack of transportation to treatment locations, or not being accessible by phone.

Additional short-term needs include affordable medical and dental care, legal assistance, or employment - issues that otherwise supplant attending to psychological needs. In regards to long-term service, clients may need assistance with job training, job placement, education, family reunification, mental health treatment, and repatriation in some cases ${ }^{3}$.

A first impediment is the bureaucracy and fragmentation of social service providers. Victims often cannot manage crises individually and lack the immediate help of a person. The social assistance system has been developed in this respect. The immediate aim of the social assistance system is to find solutions to the immediate problems of victims and their longterm rehabilitation and to achieve a standard of living similar to that existing in society.

\footnotetext{
${ }^{2}$ Morano-Foadi, S. (2016) 'Human trafficking and the position of 'vulnerability' for victims in Europe', Int. J. Migration and Border Studies, Vol. 2, No. 3, p.299-303

${ }^{3}$ Pascual-Leone, A. (2016) "Working with Victims of Human Trafficking" The Journal of Contemporary Psychotherapy, p.132
} 


\section{VICTIMS}

Social assistance is extremely important in helping the victim's psychological support, overcoming their traumas, reintegrating into society and reducing the risk of a new trafficking situation.

\section{THE NATIONAL SYSTEM FOR THE PROTECTION OF VICTIMS OF TRAFFICKING IN HUMAN BEINGS.}

The present work refers to several reports by The National Agency Against Trafficking In Human Beings (ANITP), mainly the social study "Analysis of assistance services for victims of trafficking in human beings" - $2016^{4}$ and the "National report on the evolution of trafficking in Human beings" - $2018^{5}$.

According to the data contained in the 2016 study in Romania, there were nine government centres to assist and protect adult victims of trafficking in human beings established under Law 678/2001, but the quality of the social services provided was considered problematic.

The main dysfunction mentioned is that 5 out of the 9 centres did not function in 2015 . Furthermore, the operational centres provided incomplete or financially conditional services, which did not meet the serious needs of victims. A particular problem was the assistance of victims in counties without assistance centres. The alternative solution for these victims was short-term emergency assistance ( 72 hours) provided by the county social assistance institutions (DGASPC). The quoted study points to situations where victims have been denied support against the background of budgetary inadequacies and lack of funds.

The study also notes that victims of trafficking in human beings were conditioned to participate in the criminal proceedings to be able to receive social assistance for a period longer than 90 days, despite the recommendations of the European Union. We consider this practice to be devoid of any empathy to the psychological complexity of the status of victim and the trauma suffered by them. As studies showed there are factors "which are of subjective relevance for the victims, influencing their willingness to cooperate with the police and to testify against traffickers in court. The factors were related to offender strategies (e. g. violence, deception), to police action (e. g. checks, interrogations) or to the person of the victim herself (e.g. residence status, migration goals, language, attitude towards prostitution)" ${ }^{\prime \prime}$. Moreover, the deprivation of victims of assistance can increase the risk of retrafficking exponentially, making all activities with the victim unnecessary by social workers.

After 2016, national authorities have made efforts both to prevent and protect victims and to bring national legislation in line with Community law. As a result of these approaches, the "national report on the evolution of trafficking in Human beings" 2018 States that 236 beneficiaries have benefited from services tailored to their individual needs, as set out in the aid plans.

Assistance services were offered to victims based on their informed and freely expressed consent, and the waiver of assistance was also their option. The majority of victims were protected in public institutions (133) while 70 were NGO beneficiaries and 33 received public-private partnership services.

Services provided to victims, where appropriate, by public institutions, by NGOs or in public-private partnerships are: Accommodation, assistance centers for victims of trafficking in human beings or other residential centers; health care; psychological counselling; financial aid; material aid (clothing, medicine, food, hygiene-health products); legal advice/assistance; school reintegration; professional counselling; professional retraining; reintegration into employment. According to ANITP, protection and assistance services have been provided to

\footnotetext{
${ }^{4}$ http://anitp.mai.gov.ro/p3336/

5 http://anitp.mai.gov.ro//ro/docs/studii/Raport\%20national\%202018.pdf

6 Helfferich, C. Kavemann, B. Rabe, H. (2011) "Determinants of the willingness to make a statement of victims of human trafficking for sexual exploitation in the triangle offender-police-victim" Trends in Organized Crime, Vol. 14, p.125
} 
victims of trafficking in human beings either in government/public assistance and protection centres or shelters of non-governmental organizations or in public-NG partnership. The options for services to victims are individualized, in each particular case, according to the needs and situation of each victim.

Local authorities and NGOs shall, whenever necessary, identify the most favourable opportunity for hosting and assisting each victim. The assistance aimed to ensure conditions for the normalization of the life of victims, noting that Romanian legislation and social practice do not discriminate, in assisting victims of trafficking in human beings, based on nationality. Foreign citizens' victims benefit from the same assistance services as Romanian citizens.

Another necessary observation is that there is no longer any legal conditionality for the protection and assistance of victims, which is determined by the time or the participation of victims in criminal proceedings or their cooperation with judicial authorities. We welcome this change of approach as studies show that, not all the time, excessively punitive legislation leads to the eradication of a phenomenon. Such an example could be the Spanish system, described as having "a harsh punishment component but little support for victims, and which lacks the resources to promote their social integration, and specifically, to promote human rights (...) a system destined to perpetuate the problem, allowing thousands of people to be reduced to mere objects that are bought and sold". 7

The protection services for recovery and reintegration are planned and provided based on an individualized victim assistance plan, periodically reassessed and adapted to the evolution of the situation of victims and how to achieve the objectives set.

This plan shall be followed by the specialists involved, pending completion, with the participation and consent of the victim. It is also not without importance that the level of protection of victims against possible retaliation by traffickers is dimensioned concerning the risk assessment carried out by specialized structures to combat trafficking in human beings.

\section{DEVELOPMENTS IN NATIONAL LEGAL REGULATIONS.}

The identification, protection and fulfillment of the immediate needs of victims of trafficking in human beings (THB) are an essential requirement for a trafficked person to get access to victim's protection and victim's rights established in international instruments, including EU Directive 2011/36/EU. ${ }^{8}$

The impact of this phenomenon is not strictly limited to the Romanian population. Romania's entry into the European Union in 2007 and the large influx of trafficked persons forced Member States to change their internal policies to prevent and protect victims 9 .

As an EU country and a signatory to European and international rules on preventing and combating trafficking in human beings, Romania has implicitly assumed an obligation to comply with them and to report regularly to various European and international bodies on the responsibilities assumed by the content of these regulations.

National authorities are working on trafficking in human beings with a series of concepts and regulations common to state and institutional partners. We will briefly review some applicable legal concepts and definitions.

Trafficking in human beings is defined in Article 210 of the Romanian Penal Code as: (1) The Recruitment, transportation, transfer, accommodation or receipt of a person for the purpose of its exploitation, committed: A. by coercion, kidnapping, deceit or abuse of authority; B. taking advantage of the impossibility to defend or express the will or the

\footnotetext{
${ }^{7}$ Javier De León, F. (2010) "Spanish legislation against trafficking in human beings: punitive excess and poor victims assistance", Crime Law Soc Change, Vol. 54, p.342

${ }^{8}$ Directive 2011/36/EU of the European Parliament and of the Council of 5 April 2011 on preventing and combating trafficking in human beings and protecting its victims, and replacing Council Framework Decision 2002/629/JHA [2011] OJ L 101/1.

${ }^{9}$ Caneppele, S. Mancuso, M. (2013) "Are Protection Policies for Human Trafficking Victims Effective? An Analysis of the Italian Case", European Journal on Criminal Policy and Research, Vol. 19, pp. 265
} 


\section{VICTIMS}

manifest vulnerability of that person; by offering, accepting, accepting or receiving money or otherwise giving consent to that person. The offence is punishable by imprisonment from 3 to 10 years and a prohibition on the exercise of rights. (2) Trafficking in human beings by a public official in the performance of his duties shall be punishable by imprisonment from five to 12 years. The victim consent shall not be justifiable.

Trafficking of minors as defined by Article 211 Penal Code: (1) Recruitment, transportation, transfer, housing or reception of a minor for his or her exploitation shall be punishable by imprisonment from 3 to 10 years and a prohibition on exercising rights. (C) the act has endangered the minor's life; (d) the act has been committed by a minor's family Member; (e) the act has been committed by a person in the education, child, or a recognized minor, or a recognized minor's place of care. The Victim'S Consent shall not be justifiable.

Exploitation of a person means, in the sense of Article 182 Penal Code: (A) forced labour or service; (b) slavery or other similar means of freedom or servitude; (c) obligation to practice prostitution, pornography for the production and dissemination of pornographic materials or other forms of sexual exploitation; (d) obligation to practice begging for human beings, or illegal remove of organs;

We see the conceptual harmonization of national legislation with the provisions of Article 4 of the Council of Europe Convention on the fight against trafficking in Human beings, Warsaw, 2005, Article 12 of Directive 2011/36/EU of the European Parliament and of the Council on preventing and combating trafficking in human beings and protecting its victims and Article 3 of the Protocol on the prevention, repression and punishment of trafficking in human beings, in particular women and children, supplementing the United Nations Convention against transnational organized crime, transposed into national law by Law 678/2001 on the prevention and fight against trafficking in human beings, as amended and supplemented by Law 230/2010 - also taken up in the Penal Code Article 210 (3).

As of 2019, the government has extended the protection measures that victims of crime will have access to, through an emergency ordinance that came into force on 10 April. Among the most important new measures is the creation of specialized compartments to support victims of crime or the provision of individualized services, depending on the victim.

The Emergency Ordinance No 24/2019 for amending and supplementing Law No $211 / 2004$ on certain measures to ensure the protection of victims of crime, as well as other legislation, was published in Official Gazette No 274 (of 10 April 2019) and introduced many additional safeguards for victims of crime.

Firstly, it is about measures to set up the structures referred to above. They will be set up both within the Directorate-General for Social assistance and Protection of the Child (where psychologists, lawyers and social workers will exist) and in other institutions (for example, in the case of victims of domestic violence, support and protection measures will be provided by institutions specializing in preventing and combating domestic violence). services.

Also, support and protection services can be provided by private providers of social

In terms of tasks, these structures will: Inform victims of their rights; inform and advise victims of crime of the risks of secondary or repeat victimization, of intimidation and retaliation; inform victims of crime of the financial and practical aspects of the crime after the crime; provide social integration/reintegration services, and emotional and psychological support for social reintegration; inform and advise the victim of their role in criminal proceedings (excluding legal assistance); and provide advice, if needed, or advice.

Before accessing such services, the victim will also be assessed to be able to provide support according to the victim's needs. Evaluations will also be carried out to avoid secondary victimization. Thus, medical/psychological assessments or statements, for example, will be kept to a minimum.

Secondly, the order also introduced other protective measures. One example is the creation of a special register of victims of crime to be supported by specialist services. That 


\section{Andrei Armeanu}

register will be organized at the level of the Directorates-General for Social assistance and Child Protection. The register will contain data on victims benefiting from protection and support measures. These data will be maintained for one year and can also be used by criminal bodies. The EO No 24/2019 aimed to fully transpose European Directive No 2012/29/EU ${ }^{10}$, that has not been fully transposed by April 2019.

\section{CONCLUSION}

Trafficking in human beings can be considered one of the most complex crimes. It has a multitude of operating modes that share the specific mentality of both the trafficker and the victim. More seriously, the minimum risks and investments and consistent profits make this crime the preference of transnational criminal groups.

Beyond the complexity that distinguishes this crime from others is the psychological impact on the victim, de-humanized and transformed into a means of gain. In the case of trafficking in human beings, unlike other crimes, the exploitation of victims sometimes occurs until their death. It is thus clear that any approach to trafficking in human beings must focus on the rights of the victim. We therefore welcome the recent legislative changes and the desire of the domestic legislator to emphasize social assistance for victims of human trafficking.

Even if that the victim's participation in criminal proceedings is essential, the special circumstances of the case must not be ignored, such as: the fear that victims feel when they leave the trafficking process, distrust in law enforcement bodies, trauma that they have suffered, and the direct or indirect influence of traffickers on them.

We believe that a 90-day assistance period provided by law is not enough to remove the traumas suffered. From the human rights perspective, any conditionality of access to assistance should be abandoned through participation in criminal proceedings.

European law also stipulates that victims have the right to have access to existing mechanisms for compensation for victims of violent and intentional crimes, and Member States should promote measures to encourage offenders to properly compensate victims in criminal proceedings. In Romania, the authorities are finding it difficult to deal quickly with human trafficking judicial trials and the victims are finding it difficult to access any civil compensation. At the same time, this situation also affects the ability of victims to recover their own assets under seizure in the course of criminal proceedings.

It would be appropriate to introduce simplified judicial procedures to require traffickers to pay compensation for victims and to establish a State aid fund for victims of trafficking in human beings.

\section{REFERENCES:}

Pascual-Leone1, A. (2016), "Working with Victims of Human Trafficking" The Journal of Contemporary Psychotherapy, pp. 127-135

Helfferich, C. Kavemann, B. Rabe, H. (2011) "Determinants of the willingness to make a statement of victims of human trafficking for sexual exploitation in the triangle offenderpolice-victim" Trends in Organized Crime, Vol. 14, pp.125-147

Javier De León, F. (2010), "Spanish legislation against trafficking in human beings: punitive excess and poor victims assistance", Crime Law Soc Change, Vol. 54, pp.381-409

Morano-Foadi, S. (2016) 'Human trafficking and the position of 'vulnerability' for victims in Europe', Int. J. Migration and Border Studies, Vol. 2, No. 3, pp.289-307

Caneppele, S. Mancuso, M. (2013) "Are Protection Policies for Human Trafficking Victims Effective? An Analysis of the Italian Case", European Journal on Criminal Policy and Research, Vol. 19, pp. 259-273

10 Directive 2012/29/EU of the European Parliament and of the Council of 25 October 2012 establishing minimum standards on the rights, support and protection of victims of crime and replacing Council Framework Decision 2001/220/JHA [2012] OJ L 315/57. 
Directive 2011/36/EU of the European Parliament and of the Council of 5 April 2011 on preventing and combating trafficking in human beings and protecting its victims, and replacing Council Framework Decision 2002/629/JHA [2011] OJ L 101/1.

Directive 2012/29/EU of the European Parliament and of the Council of 25 October 2012 establishing minimum standards on the rights, support and protection of victims of crime, and replacing Council Framework Decision 2001/220/JHA [2012] OJ L 315/57.

http://anitp.mai.gov.ro/ 